Full reference: Armstrong, S., McLaughlin, C., Moustafa, M, W. \& Elamer, A.A., (2021) 'Audit committee diversity and corporate scandals: Evidence from the UK', International Journal of Accounting and Information Management, forthcoming. (Accepted 12 August 2021).

\title{
Audit committee diversity and corporate scandals: Evidence from the UK
}

\section{Stephen Armstrong}

Strathclyde Business School, University of Strathclyde, Glasgow, G1 1XQ, Scotland

\section{Craig McLaughlin}

Strathclyde Business School, University of Strathclyde, Glasgow, G1 1XQ, Scotland

Email: craig.mclaughlin@strath.ac.uk

\section{Maha W. Moustafa}

School of Computing, Electronics and Maths, Coventry University, UK; and Department of Applied Statistics \& Insurance, Mansoura University, Egypt Email: ad5625@coventry.ac.uk

\begin{abstract}
Ahmed A. Elamer *
Brunel Business School, Brunel University London, Kingston Lane, Uxbridge, London, UB8 3PH $\mathrm{UK}$; and Department of Accounting, Faculty of Commerce, Mansoura University, Mansoura, Egypt Email: ahmed.a.elamer@gmail.com

*Corresponding author
\end{abstract}




\title{
Audit committee diversity and corporate scandals: Evidence from the UK
}

\begin{abstract}
Purpose -This paper empirically analyses specific characteristics of an audit committee that could be associated with the likelihood of corporate fraud/scandal/sanctions.

Design/methodology/approach -The sample includes all firms that were investigated by the Financial Reporting Council (FRC) through the audit enforcement procedure from 2014 to 2019, and two matched no-scandal firms. It uses logistic binary regression analysis to examine the hypotheses.
\end{abstract}

Research findings- Results based on the logit regression suggest that audit member tenure and audit committee meeting frequency both have positive associations to the likelihood of corporate scandal. Complementing this result, we find negative but insignificant relationships among audit committee female chair, audit committee female members percentage, audit committee qualified accountants members, audit committee attendance, number of shares held by audit committee members, audit committee remuneration, board tenure and the likelihood of corporate scandal across the sample.

Practical implications - The results should help regulatory policy-makers make decisions which could be crucial to future corporate governance. Additionally, these results should be useful to investors who use corporate governance as criteria for investment decisions.

Originality/value - We extend, as well as contribute to the growing literature on audit committee and therefore wider corporate governance literature and provide originality in that it is the first, to our knowledge, to consider two characteristics (i.e., remuneration and gender) in a UK context of corporate scandal. Also, the results imply that the structure and diversity of audit committee affect corporate fraud/scandal/sanctions.

Keywords: Audit committee diversity; audit committee structure; corporate scandals; corporate governance; UK 


\section{Introduction}

A series of high-profile scandals of past three decades beginning with Enron, to the 2008 financial crisis, to recent cases such as Carillion, have led to a greater focus on corporate governance to protect shareholders with a specific focus on audit committee structure (ElDyasty \& Elamer, 2020; Elamer et al., 2018, 2019a, 2020; Ghafran and O'Sullivan, 2017; Karim et al., 2013; Li \& Song, 2018; Yu \& Wang, 2018). This study seeks to understand further the impact and importance of the audit committee in preventing corporate scandals. Audit committees remain trusted as a vital tool in the UK Corporate Governance Code, which is yet to receive much focus in terms of audit committees and fraud/scandal/sanctions. Thus, in this study, we make an effort to bridge the gap in financial reporting quality literature by examining the relationship between audit committee diversity and structure and the likelihood of corporate fraud/scandal/sanctions.

The Corporate Governance Code in the United Kingdom ("UK") has gone through several long processes and improvements from its inception in 1992 to the current version seen today (Bufarwa et al., 2020; CGC, 2018; Elamer \& Benyazid, 2018; Elmagrhi et al., 2017; Feng et al., 2020). Originally the code was developed from recommendations of the Cadbury Committee which took the view that greater corporate governance control mechanisms were needed such as subcommittees (e.g., audit committee) (Agyemang-Mintah \& Schadewitz, 2018, 2019; Albitar et al., 2020a,b; Karim et al., 2013; Li \& Song, 2018; Yu \& Wang, 2018). Further developments were then made after UK reports such as the Higgs report and Smith Committee in 2003, which made recommendations on the corporate governance process and audit committee oversight respectively. The last significant revisions to the code were made in 2018, which was changed to consider The Green Paper Consultation and the Financial Reporting Council's ("FRC") culture report. These changes always look to protect the shareholders and the accountancy profession in promoting truth, fairness and transparency 
(AlHares et al., 2020; Alshbili \& Elamer, 2019; Elamer et al., 2020b; Elmagrhi et al., 2018). Yet, over the past few decades, there has been a long list high profile corporate scandals with the most recent to this study being Thomas Cook. This research to a degree investigates the effectiveness of the current 2018 UK Corporate Governance Code in terms of the audit committee guidance. Recent corporate scandals have sparked debate over the usefulness of the current version the UK Corporate Governance Code of which a key area is the audit committee under 'Audit, Risk and Internal Control'. One of the audit committee's main duties is to ensure the protection of shareholder's interests through overseeing the firm's financial reporting. Thus, instances where the FRC see fit to announce public investigations of a firm it can be seen as a failure of the audit committee's monitoring duties.

It is crucial to investigate the audit committee structure and diversity for several important reasons. Firstly, many audit committee members suggest that lack of time is the principal challenge to strong governance because of handling speedily expanding tasks and workload demands (KPMG, 2013) driven by the current regulations and governance initiatives (AbdelFattah et al., 2020; CGC, 2018). Unintentional costs of these fresh responsibilities include sharp litigation and reputational risks, and, subsequently, members maybe unwillingness to participate on audit committees, thus minimise the pool of audit committee members and extra growing workload pressure (Linck et al.,2009; Sharma et al., 2020). Secondly, the audit committee is a board of directors subcommittee, and therefore, a member working on several boards may not inevitably work on those boards' audit committees. Thirdly, diverse boards' audit committees instruct more general, strategic, and performance-oriented experiences. Hence, diverse boards' audit committees may mitigate the likelihood of corporate fraud/scandal/sanctions.

This research contributes to a growing literature on audit committee and therefore wider corporate governance literature (Alnabsha et al., 2018; Alshbili et al., 2019; Elamer et al., 2019) 
and provides originality in that it is the first, to our knowledge, to consider two characteristics in a UK context of corporate scandal. These two characteristics are the most recent areas of audit committee research in remuneration and gender. Our distinctive dataset on earlier corporate fraud/scandal/sanctions allow us to explore the association between audit committee characteristics and the likelihood of corporate fraud/scandal/sanctions made in actual practice. Utilising these data, we find some audit committee characteristics attenuate the occurrence of corporate fraud/scandal/sanctions. We conduct our analyses using detected fraud/scandal/sanctions by FRC that happened in the financial reports during the period 2014 to 2019. We find that audit member tenure and audit committee meeting frequency both have positive associations to the likelihood of corporate scandal. Complementing this result, we find negative but insignificant relationships among audit committee female chair, audit committee female members percentage, audit committee qualified accountants members percentage, audit committee attendance, number of shares held by audit committee members, audit committee remuneration, board tenure and the likelihood of corporate scandal across the sample.

Also, by considering audit committee diversity and structure, we expand the current literature by offering evidence that boards' audit committees members tenure and meeting frequency may indicate red flags to investors. Our results suggest that future research should consider audit committee diversity with the most often analysed audit committee structure. In summary, these results imply that the structure and diversity of audit committee affect corporate fraud/scandal/sanctions.

We proceed as follows. Section 2 discusses previous literature and hypotheses development. Section 3 introduces the research method. We present the results and discussion in Section 4. Section 5 concludes our research, and we provide limitations and future studies. 


\section{Extant Literature and Hypotheses Development}

\subsection{Audit committee gender diversity}

There is no current gender quota in the UK Corporate Governance Code 2018, but diversity is encouraged as it has many benefits (Gavious et al., 2012; Khatib et al., 2021; Velte, 2018). Females have been shown to be more likely to discuss difficult issues, more fiscally conservative, better monitors, less tolerant to opportunistic behaviours, and more risk-averse (Chen et al., 2016; Roden et al., 2016). It comes as no surprise that gender diversity is an area that is taking greater academic focus since the traits above are important in the boardroom, and on their sub-committees such as the audit committee. Gavious et al. (2012) argue females on the audit committee help mitigate aggressive accounting decisions through their significant earnings management findings which support the claim of females being more risk averse. Females have also theorised to be more ethical in their judgements and behaviours their male counterparts (Kaplan et al., 2009; Vermeir and Van Kenhove, 2007). Kaplan et al. (2009) found females are more likely to report fraudulent financial reporting, which in the context of this study should see the presence of females reduce the likelihood of FRC investigation.

Parker et al. (2017) and Wilbanks et al. (2017) find a significant and positive relationship between female members and both the reporting of control problems and fraud risk monitoring in financial reporting, respectively. These suggest greater diversity contributes to increased reporting quality and management assessment, a view supported by Harjoto et al. (2015). Ittonen et al. (2010) similarly suggest that audit committees with female chairpersons reduce the inherent risk of a misstatement by improving the enhancing the financial reporting process. Contrary to this, Chen et al. (2016) and Abbott et al. (2012) argue that although greater female board representation has many benefits ${ }^{1}$, this is not driven by females on the audit committee.

\footnotetext{
${ }^{1}$ Chen et al (2016) argue it mitigates material weakness while Abbott et al (2012) argue females are much more likely to be independent and lower the likelihood of financial restatement
} 
Velte (2018) and Wilbanks et al. (2017) also find a positive relationship between the percentage of females on audit committees and auditors' disclosures and readability of key audit matters, measured by the Flesch reading ease index at the $1 \%$ level. These studies suggest there are benefits to gender diversity on the audit committee and firms should seek for this. Finally, Thiruvadi and Huang (2011) find consistent evidence to show the presence of female directors on the audit committee constrains earnings management. However, Sun et al. (2011) find no significant association between female audit committee representation and earnings management. Therefore, this paper's final hypotheses are:

$H_{1}$ : Audit Committee female representation has a significant effect on the likelihood of corporate scandal.

$\mathrm{H}_{2}$ : Audit Committee Chair female representation has a significant effect on the likelihood of corporate scandal.

\subsection{Audit committee financial expertise}

The UK Corporate Governance Code 2018 sets provisions that on the establishment of the audit committee the board should be satisfied that at least one member has recent and relevant financial experience but has avoided any attempt at defining it and leaves it up to the company to decide (FRC, 2018). The FRC did consider changing this to one member with competence in accounting and/or auditing, however, after consulting the industry, this was decided against including in the 2016 version of the UK Corporate Governance Code (Ghafran and O'Sullivan, 2017). SOX in America is stricter with accounting expertise and certain types of nonaccounting (finance and supervisory) expertise accepted (Abernathy et al., 2014). This has led to a great debate in academic literature with studies in both the broad definition and some that break the definition into specific parts to test whether it is currently too lenient. This is an important factor in the audit committee because aspects of the financial reporting process and 
other responsibilities may involve requiring a strong understanding of the accounting framework and in-depth knowledge to fulfil the role to the best of their ability.

Abernathy et al. (2014) in their 2006-2008 sample study focussed solely on financial expertise on the audit committee and its relationship with financial reporting timeliness. They break down financial expertise to those with accounting financial expertise gained from education or experience in accounting, those with accounting financial expertise gained from being a Chief Financial Officer (“CFO”), and non-accounting financial expertise which is still accepted in some cases under SOX. They find that public accounting financial expertise is significantly and negatively associated with earnings announcement lag, audit report lag, and United States Securities and Exchange Commission ("SEC") late filings which are all important factors of financial reporting timeliness. They did, however, find no association for both CFO financial expert and non-accounting financial expert. This may be down to the varying backgrounds of CFO's due to the variety of work within the role they not always possess the technical accounting knowledge concerning, for example, accounting policies or unusual transactions that would be expected those with accounting experience or qualifications. Abernathy et al. (2014) find the same results when tested specifically on the audit committee chair. In a similar study, Wu et al. (2016) find that timely going-concern modifications prior to failure are more likely when the audit committee has a financial expert, at the $1 \%$ level $^{2}$. This timing is important as it is often evidence of audit failure and linked to corporate governance, most recently this happened with Thomas Cook. The only UK study so far to separate the financial expert definition to any extent, is Ghafran and O'Sullivan (2017). In their study, they find audit fees are lower when financial experts are from accounting as opposed to non-accounting backgrounds. This could be due to a lack of specific accounting knowledge, so non-accounting

\footnotetext{
${ }^{2} \mathrm{Wu}$ et al. (2016) use the broad financial expert definition. This definition does not distinguish between accounting, financial, and supervisory. All of which can be used to justify 'financial' expertise
} 
finance experts push for more extensive audits for greater self-assurance than accounting experts.

Appiah and Chizema (2017) and Owens-Jackson et al. (2009) find no significant relationship between having a financial expert on the audit committee and corporate insolvency or fraudulent financial reporting, respectively. Contrary to this, Farber (2005) finds that fraudulent firms tend to have fewer financial experts on their audit committee. This difference is particularly interesting as both Farber (2005) and Owens-Jackson et al. (2009) used sample firms from SEC filing records. Badolato et al. (2014) similarly study the relationship between financial expertise and accounting irregularities, a measure of severe earnings management. They find financial, accounting, and CFO based expertise all insignificant. They do, however, find supervisory experience (non-financial) when combined with seniority is negative and significant. This suggests non-financial experts are possibly better at identifying non-recurring accounting issues and have a greater influence of irregularity deterrence. Interestingly, Ghosh et al. (2010), and Sun et al. (2014) find no significant evidence to suggest the presence of financial experts, using broad and narrow definitions respectively, on the audit committee is associated with earnings management. This is an interesting revelation as it can be reasonably expected that financial competence would improve a committee's ability to monitor earnings management by the board.

Kelton and Yang (2008) and Mangena and Pike (2005) find a positive and significant relationship between audit committee financial expertise and corporate disclosure. Interestingly, Li et al. (2012) find no significant relationship between audit committee financial expertise and disclosure. Financial experts would be expected to have a greater understanding and therefore be able to ask more technical questions of management and challenge management where necessary, which should, in theory, enhance transparency, yet results are inconsistent around disclosure. The evidence for accountancy financial experts is strong, and 
there is some evidence to suggest the benefits of the non-accountancy financial experts as well. The current loose definition may be an area the FRCs successor, the Audit, Reporting and Governance Authority assess again in the future as literature in this area develops. Therefore, the third and fourth hypotheses are:

H3: Audit Committee professional accountancy qualifications have a significant effect on the likelihood of corporate scandal.

H4: Audit Committee audit experience has a significant effect on the likelihood of corporate scandal.

\subsection{Audit Committee Member Tenure}

There are currently no provisions in the UK Corporate Governance Code 2018 around audit committee tenure, only that after nine years on the board non-executive directors could be deemed no longer independent. This link to tenure could be viewed in the same way as a key audit partner in that after a certain amount of time it can be argued there is a familiarity threat, and a fresh pair of eyes could help (Vafeas, 2003, 2005). On the other hand, longer tenures can be expected to build firm-specific knowledge and understand their financial reporting process and in a better position to fulfil their responsibilities (Liu and Sun, 2010).

Badolato et al. (2014), Bedard et al. (2004), and Ghosh et al. (2010) find audit committee member tenure to be significantly and negatively associated with abnormal and discretionary accruals which suggest longer tenure is linked to constraining earnings management. In contrast, Ghosh et al. (2010) find that absolute discretionary accruals decrease by $0.1 \%$ of total assets for every additional year of audit committee tenure, all else equal. Badolato et al. (2014) treat longer tenure as status and seniority on the committee, and the worst frauds occur when senior board members successfully undermine the audit committee, such as Enron (Thompson, 2003). These views are supported by Yang and Krishnan (2005) who also find tenure is 
negatively related to earning management, suggesting on-the-job experience has positive monitoring effects. This may also be because a lack of seniority damages a member's ability to scrutinise since senior members are less prone to group pressures and have greater assurance in asking challenging questions (Persons, 2008). This contradicts Sun et al. (2014) and Garven (2015) who find no relationship between tenure and earnings management.

Owens-Jackson et al. (2009) find no significant evidence of a relationship between committee tenure and fraudulent financial reporting. This is complemented by Abernathy et al. (2014) who find evidence of a positive association between tenure and financial reporting quality with audit committee tenure negatively and significantly linked to audit report lag. This suggests that there are benefits to longevity and with greater understanding audit members can excel in their roles and responsibilities such as help deliver financial reporting quality. Contrary to this Sharma and Iselin (2012) find a positive and significant association between member tenure and financial misstatements, which could also suggest directors with longer tenure do not exercise independent judgement, a view supported by Kim et al. (2013). Therefore, the eighth hypothesis is:

$H_{5}$ : Audit Committee member tenure has a significant effect on the likelihood of corporate scandal.

\subsection{Audit committee independence}

The UK Corporate Governance Code 2018 requires that the audit committees should consist of independent non-executive directors, which is a legal requirement of SOX. The audit committee is the ultimate board-level overseer of the financial reporting process ensuring objectivity, honesty, and protecting the external auditor from any undue influences (Archambeault et al., 2008). It is reasonably possible that if the audit committee independence was compromised in any way, then they may not assess or monitor management with the clear 
judgement that is expected of them. There is no clear definition of independence to go by in the UK Corporate Governance Code 2018, leaving it up to the board themselves to determine if each director is independent in character and judgement (Enriques, 2003). However, there are characteristics that could be considered to compromise independence, such as excessive compensation or shareholding in the company of audit committee members as these represent financial interests. Previous studies tend to treat it as no affiliation - not recently employed, no relatives within management, not a professional advisor to the firm (Agrawal and Chadha, 2005; Carcello and Neal, 2000; Klein, 2002) - whilst one suggested it should be taken from an investor's perspective, essentially independence in mind rather than form (Ferreira, 2008).

Independence has been one of the most broadly studied characteristics of audit committees. Uzun et al. (2004) sample fraud firms against matched no fraud firms and find a higher degree of independence in the audit committee significantly reduces the likelihood of fraud. This confirms the view of Abbott et al. (2000) and Owens-Jackson et al. (2009) who find independence as a key driver in fraud. Owens-Jackson et al. (2009) also find that even when audit committees were fully independent the likelihood of fraudulent financial reporting did not decrease below 28\%, suggesting that although audit committees can help mitigate fraud, there are limitations to their influence and that responsibility ultimately falls on management rather than the committee. Independence, therefore, has an association effect rather than causation. Contrary to these, Agrawal and Chadha (2005) find that when audit committee independence is looked at in isolation, it is unrelated to the probability of restated earnings and only becomes significant if combined with financial expertise. Persons (2009) uses a similar method of fraud/no-fraud matching to investigate the likelihood of early disclosure ${ }^{3}$. Persons (2009) finds that audit committee independence is positively associated with early disclosure

\footnotetext{
${ }^{3}$ A glossary of disclosures used by authors within this paper can be found in Appendix 2.
} 
and therefore, more ethical financial reporting and being less likely to engage in fraudulent financial reporting.

Further to this Carcello and Neal (2000) find that audit firms are less likely to issue modified going-concern reports to financially distressed clients whose audit committees lack independence, showing a hesitation if subsequent dismissal is implied by management. Carcello and Neal (2003) further develop this in their study of auditor dismissals following the issue of new modified going concern reports to show how audit committees and auditors can work together to enhance corporate governance ${ }^{4}$. Their significant findings are more independent audit committees are more effective in protecting external auditors from dismissal following new modified going concern reports and that the independent members experience a significant turnover rate post auditor dismissal. In a similar UK study, Wu et al. (2016) find that audit committee independence is positively associated with the likelihood of going concern modification prior to failure. The issuance of a clean report when it should have been a going concern is exactly the type of scenario that an auditor fears and leads to an investigation from the FRC, which damages the credibility of the accounting profession. In a similar UK study focussed on insolvency, Appiah and Chizema (2017) find audit committee independence negatively and significantly related to corporate insolvency. Using a sample of 692 publicly traded US firms, Klein (2002) finds a negative relationship between audit committee independence and abnormal accruals is discovered, suggesting that greater independence helps constrain earnings management and therefore enhances committee effectiveness as an overseer. In terms of disclosure Li et al. (2012) also finds no relationship between audit committee independence and disclosure.

\footnotetext{
${ }^{4} \mathrm{~A}$ going concern report is considered new when the client received an unmodified (clean) report the previous year
} 
One proxy for independence mentioned above is excessive remuneration. Audit committee members who are paid excessive remuneration could have their independence compromised by the financial incentive since it creates an alignment between them and the hand that feeds them (Barrier, 2002). Another theory is that excessive compensation may be a symptom of cronyism between directors who believe future income depends on a bias (Magilke et al., 2009; Persons, 2012). This is shown by Habbash et al. (2013) whose study of FTSE 350 companies between 2006 and 2007 found a significantly positive relationship between average audit committee member remuneration and upwards earnings management in one of their models ${ }^{5}$. In another study, Persons (2012) finds no significant association between fraudulent financial reporting and cash remuneration. Campbell et al. (2015) offer some support of this where they find no significant relationship between audit committee remunerations and the likelihood of the firm beating analysts' forecasts.

On the other hand, it is important to consider that greater remuneration may motivate objectivity as the members are paid more fairly for their skills. Engel et al. (2010) argue this link through the positive relationship between cash remuneration and audit fee, their proxy for financial monitoring. Rickling and Sharma (2017) support this with evidence suggesting that as cash-based remuneration to audit committee members is not linked to firm performance, greater or even deemed excessive amounts do not motivate short-term focus or compromise their independence. Together these suggest that cash remuneration increases objectivity and should help reduce the likelihood of corporate scandal, a view supported by Magilke et al. (2009). It is widely accepted by the authors above that literature in this area is scarce, which creates an opportunity for greater review. Therefore, the first hypothesis is:

\footnotetext{
${ }^{5}$ Habbash et al (2013) is a paper that distinguishes between upwards and downwards earnings management. Upwards being more likely to adjust figures upwards to portray better performance while downwards would be to adjust downwards. There are motivations for performing both but it is outside the scope of this study
} 
$H_{6}$ : Audit Committee remuneration has a significant effect on the likelihood of corporate scandal.

\subsection{Audit committee share ownership}

A subset of independence is audit committee share ownership in the firm. Significant share ownership could compromise the independence of the member(s) who would then have a financial interest in the firm. There is also an argument through agency theory that significant share ownership makes audit committee members more likely better to perform their duties in the interests of shareholders because their interests would be aligned (Ghosh et al., 2010). Interestingly, Garven (2015) and Ghosh et al. (2010) find no evidence to suggest the audit committee share ownership, at any level, is associated with earnings management. Contrary to this, Sun et al. (2014) find that block shareholding by audit committee members are significantly and negatively related to real earnings management ${ }^{6}$. To add further ambiguity, Yang and Krishnan (2005) find share ownership by audit committee members to be negatively associated with earnings management. All three studies were carried out in the US and follow similar methods, so the difference in results is surprising. Klein (2002) provides some support to Sun et al. (2014) as with the finding that outside directors ${ }^{7}$ with block shareholdings are more effective at constraining accrual earnings management in US firms. Further to this, Li et al. (2012) in a 2005 UK study of 100 London Stock Exchange companies in intellectual capitalintensive sectors find audit committee member shareholding to be negatively and significantly associated with disclosure at a 5\% level. Mangena and Pike (2005) support this as they similarly find the level of disclosure decreases with the amount of share ownership held by audit committee members in their sample of 262 UK listed firms. Transparency is at the top of shareholder priorities, and these two studies together create the perception that when audit

\footnotetext{
${ }^{6}$ Real earnings management being the manipulation of cash flows measure by abnormal discretionary expenses, production costs, and cash flows from operations

${ }^{7}$ Outside directors are non-executive directors who aren't involved in the day to day running of the business
} 
committee share ownership is high, their independence and criticalness of management is compromised, an agency theory issue. A possible reason for this is negative disclosure can adversely affect company value. Carcello and Neal (2003) found that as share ownership of audit committee members increased, and they were less likely to protect auditors following unfavourable report issuance, suggesting their independence diminishes as their ownership stake grows. In terms of a board, shareholding is normally used to align management interests with that of shareholders for more positive outcomes and reduce agency costs. So, surprisingly, current studies seem to show audit committee member shareholdings to have adverse effects. Audit committee independence is by no means the likely causation of any one of these, but it is an important factor associated with many of them. Therefore, the second hypothesis is:

H7: Audit Committee share ownership has a significant effect on the likelihood of corporate scandal.

\subsection{Audit committee size}

The UK Corporate Governance Code 2018 provisions set out that on the establishment of an audit committee, there should be no fewer than three independent board members, or for smaller firms 2 (FRC, 2018). The size of the audit committee is important as more members should, in theory, increase the diversity of gender, ethnicity, and with that skills, views, experiences and expertise on the committee (Madi et al., 2014). This should then be combined with greater resources available, particularly time, to fulfil the roles and responsibilities to the level expected.

Wilbanks et al. (2017) and Sharma and Iselin (2012) find that audit committee size is significantly and positively associated with enhanced risk monitoring of fraud in financial reporting. Agrawal and Chadha (2005) and Appiah and Chizema (2017) however found conflicting evidence as they find the size of the audit committee is not related to corporate 
insolvency. Further to this, Hoitash et al. (2009) find audit committee size is not significantly related to material weakness, a view supported by Farber (2005) and Huang and Thiruvadi (2010) who find it has no relation to the likelihood of SEC sanctions/fraud. It would be thought that these would have similar results since fraudulent financial reporting in many instances leads to corporate insolvency as can be seen with the ongoing liquidation of Patisserie Valerie. It is possible that the differences are down to different regulatory landscapes of the US and the UK setting where the latter has a greater degree of flexibility in their liberal principles-based approach (Habbash et al., 2013; Wu et al., 2016).

Ghosh et al. (2010), Liu and Sun (2010) and Yang and Krishnan (2005) find a significant and negative relationship between audit committee size and earnings management and therefore poorer quality of financial reporting. This is supported by MacGregor (2012), who says larger audit committees are more effective at rejecting aggressive policies designed to meet earnings thresholds. This suggests that larger audit committee boards are more effective at constraining earnings management, which could be due to a higher likelihood of directors possessing the relevant accounting knowledge and experience. Garven (2015), He and Yang (2014), and Sun et al. (2014) provide conflicting evidence as they find no relationship between audit committee size and earnings management.

Li et al. (2012) and Persons (2008) find that audit committee size is significantly and positively associated with disclosure at the level of $5 \%$ and $1 \%$ level, respectively. This contradicts the evidence of Mangena and Pike (2005) who found no relationship between audit committee size and the level of company disclosure. Although there is conflicting evidence, it may be that larger audit committees have a greater number of highly ethical members who combine to challenge the board when necessary. Therefore, the fifth hypothesis is:

$H_{8}:$ Audit Committee size has a significant effect on the likelihood of corporate scandal. 


\subsection{Audit committee activity}

The FRC has guidance on audit committees that recommends they meet no fewer than 3 times per financial year (FRC, 2016a). The frequency of meetings by the audit committee is a measure of diligence from the members as it should be accompanied by important prior research, so the meetings generate the necessary discussions and raise any important questions to go to the board. The meeting quality is largely dependent on the chair as they are charged with providing pre-meeting material, setting the agenda, controlling the discussions and helping develop member relationships, they are the nexus of the committee (Abernathy et al., 2014; Beasley et al., 2009). Activity to a degree goes together with size as they share a significant positive relationship (Al-Najjar, 2011). They suggest this may be down to greater resources, and more members create a higher demand to discuss any potential monitoring points as they arise.

Abbott et al. (2000), Farber (2005), and Owens-Jackson et al. (2009) report that the frequency of meetings has a negative and significant link to the likelihood of financial fraud. This is supported by Abernathy et al. (2014) who find audit committee meeting frequency to be negatively associated with earnings announcement lag and SEC late filings, two factors of financial reporting timeliness. These results may be because the ultimate goal of an audit committee is to protect shareholder interests in relation to financial reporting and internal control. The goal is more likely to be accomplished if members have greater opportunities to express their judgement (Madi et al., 2014). Most surprisingly Abbott et al. (2004) later contradict their earlier study where they fail to document any statistical significance between audit committee meeting frequency and the incidence of fraud, a view supported by Huang and Thiruvadi (2010) and Uzun et al. (2004). Ghosh et al. (2010) find that audit committee meeting frequency is negatively related to discretionary accruals which suggest audit committees are more reactive to escalating problems than proactive. This view is supported by Hoitash et al. 
(2009), Naiker and Sharma (2009), and Zhang et al. (2007) who find firms with material weaknesses and internal control deficiencies hold more audit committee meetings ${ }^{8}$. This is supported by Sharma and Iselin (2012) who find a positive and significant relationship between meeting frequency and the likelihood of financial misstatement. Interestingly Bedard et al. (2004) and Yang and Krishnan (2005) find no significance between audit committee meeting frequency and earnings management.

Kelton and Yang (2008), Li et al. (2012), and Persons (2008) all find a positive relationship between audit committee meeting frequency and disclosures. This suggests audit committees that meet more often tend to be more diligent and likely to request more transparency, an important factor for shareholders and management's primary communication to them (McGrane, 2009). Persons (2008) has the extra benefit of testing fraud and non-fraud firms, which therefore links audit committees which meet more often to be less prone to fraudulent financial reporting. Further to this, Appiah and Chizema (2017) find meeting frequency to be negatively and significantly related to corporate insolvency. The literature around audit committee meeting frequency is largely encouraging towards more meetings as it allows the committee to exercise greater professional care which should, in turn, improve audit and financial reporting quality and reduce the likelihood of corporate scandal. Therefore, the sixth and seventh hypotheses are:

$\mathrm{H}_{9}$ : Audit Committee meeting frequency has a significant effect on the likelihood of corporate scandal.

$H_{10}$ : Audit Committee meeting attendance has a significant effect on the likelihood of corporate scandal.

\footnotetext{
${ }^{8}$ Firms with internal control deficiencies are more likely to experience SEC/FRC actions or restatements
} 


\subsection{Audit committee other directorships}

There is, currently, no guidance on a maximum number of other directorships anyone audit committee member can hold. However, an important attribute of an effective committee is each member has sufficient time to fulfil their role (Song and Windram, 2004). These roles come with significant time commitments which grows more demanding with each additional directorship. For example, Harrast and Mason-Olsen (2007) study of 500 audit committee members found that on average, $81.9 \%$ spent over 50 hours per financial year on each committee and $43.1 \%$ spent over 100 hours. Rupley et al. (2011) support this as they conducted the same study with a different sample and found similar results in that $45.2 \%$ spent over 100 hours on the committee. Sharma and Iselin (2012) find a significant positive association between financial misstatements and audit committee members with high multiple directorships. These results supported by Song and Windram (2004) who say multiple directorships could undermine the audit committee's effectiveness, which creates an argument that time split too thinly across many committees could have an adverse impact on the committee as a whole. There may be a ceiling to this though as sitting on several audit committees should provide members with additional experiences from different scenarios and how other experienced directors tackle them. These important learning experiences could help develop and improve their own monitoring abilities. Krishnan (2005), however, found no significance between outside directorships and the incidence of internal control problems.

Sun et al. (2014) find a significant and negative association between audit committee members holding outside directorships and constraining earnings management. This is supported by Garven (2015) who find a significant and positive association between outside directorships and the occurrence of real earnings management, suggesting an excessively demanding workload may have a damaging effect on the members monitoring ability. Contrary to this, 
Yang and Krishnan (2005) and Bedard et al. (2004) find a significant and negative relationship between outside directorships and earnings management. Therefore, the ninth hypothesis is:

H11: Audit Committee outside directorships have a significant effect on the likelihood of corporate scandal.

\section{Research Method}

The method for this study is an empirical piece using quantitative logistic binary regression which runs independent variables against a dependent variable identified through binary use of 1 or 0 , in this case, corporate scandal firms. This largely follows the work of Owens-Jackson et al. (2009) and Uzun et al. (2004) who conduct similar studies in the US. To conduct this investigation, all companies from the FRC current and recently passed cases for the Audit Enforcement Procedure ('AEP') were used to avoid selection bias. Only cases where the investigation year was 2014 or later and involved Public Limited Companies ("PLC") qualified as they follow the same UK Corporate Governance Code and are within the two most recent versions of the code that had significant changes. Two were subsequently removed from the population of thirteen; one due to lack of available information, whilst another had no comparable company on the database used to find comparable companies fairly, this left a sample of eleven ${ }^{9}$ with 22 firm-year observations. This small sample can be justified by similar studies such as Peasnell et al. (2001). They investigated a matched-pairs sample of 47 companies sanctioned by the Financial Reporting Review Panel ("FRRP”) for defective statements over a greater period than this paper. A second study conducted by Song and Windram (2004) also used a matched-pairs sample of 27 firms who had adverse FRRP rulings between 1991-2000. It is, however, acknowledged that a larger sample would have allowed for more robust results.

\footnotetext{
${ }^{9}$ Appendix 1 shows the final sample of all firms.
} 
This paper follows a similar selection process to Owens-Jackson et al. (2009) who used SEC files on accounting and auditing enforcement releases, while Uzun et al. (2004) used whitecollar crime and fraud listings from The Wall Street Journal. The companies in each study were then time-matched to similar companies based on factors such as industry, size, and the exchange they are listed on. This paper used the S\&P Capital IQ database as an unbiased method of matching companies which allowed similar companies based on industry and size ${ }^{10}$ to be identified, from here the first two companies on the same exchange, or similar were selected. In the one instance where a second comparable company on the same exchange could not be found, e.g. Alternative Investment Market firm could not be matched, and then a London Stock Exchange counterpart was used which follows closely to Owens-Jackson et al. (2009). This paper has matched the AEP firms to two comparable non-scandal companies in an attempt to produce more comprehensive results. This results in 22 firms with 44 firm-year observations. Finally, the 'event year' which is the year the investigation is concerned with and the previous year was used as this will help highlight what leads to scandal.

\subsection{Research Model Specification}

To investigate whether audit committee diversity and structure influence the likelihood of corporate scandal in the UK, we employed a logistic binary regression model to test the hypotheses developed in Section 2. Given the type of data, the logistic binary regression model employed is specified below:

$$
\begin{aligned}
\operatorname{Scandal}_{i t}= & \beta_{0}+\beta_{1} \mathrm{ACFC}_{i t}+\beta_{2} \mathrm{ACF}_{i t}+\beta_{3} \mathrm{ACQ}_{i t}+\beta_{4} \mathrm{ACM}_{i t}+\beta_{5} \mathrm{ACA}_{i t}+\beta_{6} \mathrm{ACS}_{i t} \\
& +\beta_{7} \mathrm{ACD}_{i t}+\beta_{8} \mathrm{BIG}_{i t}+\beta_{9} \mathrm{ACE}_{i t}+\beta_{10} \mathrm{ACSZ}_{i t}+\beta_{11} \mathrm{ACR}_{i t}+\beta_{12} \mathrm{ACT}_{i t} \\
& +\varepsilon_{i t}
\end{aligned}
$$

\footnotetext{
${ }^{10}$ Size was measured in terms of revenue and market capitalisation
} 
Consistent with the likelihood of corporate scandal studies (Owens-Jackson et al., 2009; Uzun et al., 2004), the dependent variable in Model 1, Scandal, is a dummy variable that equals 1 if AEP firms and 0 otherwise. Twelve audit committee characteristics were chosen for consideration based on previous literature and Owens-Jackson et al. (2009). From here, eleven independent variables were chosen for comparison after one was removed due to multicollinearity. The eleven independent variables and one control variable can be viewed in Table 1, along with a description of each. Audit committee chair as female $(A C F C)$ and percentage of females on the audit committee $(A C F)$ was chosen to expand on the recent debates around gender diversity on the audit committee, which is a new contribution from this paper that was not included in previous literature of this type, to our knowledge. A qualified accountant $(A C Q)$ and audit experience (practice) $(A C E)$ were used as a proxy for financial experience, which has been commonly broken down this way and tested in other empirical research papers such as Abernathy et al. (2014) and Badolato et al. (2014). The average number of audit committee meetings $(A C M)$ and percentage of attendance $(A C A)$ is used to illustrate the activity of the audit committee; however, there is a limitation here in that the length of each meeting and nature of them is unknown, it is possible that many meetings lacked substance. The average audit committee size (ACSZ) represents the resources available to the committee in terms of knowledge, time and personnel, and to a degree goes together with activity as they share a significant relationship (Al-Najjar, 2011). Independence is now quite conclusively studied and recognised to be positive. Therefore, this paper looks at factors which could compromise that independence, such as the average percentage of shares held by audit committee members $(A C S)$. This was used in conjunction with average audit committee member compensation $(A C R)$ as this could be viewed as an agency threat. The average number of outside directorships $(A C D)$ was used as audit committee time requirements are ever more demanding, and outside directors can be viewed as either member spreading their time too 
thinly or possibly increasing their experience. The average audit committee tenure $(A C T)$ is a commonly explored variable as it can be closely linked to independence in aspect to familiarity and agency. It can also be linked to experience since, over time, firm-specific knowledge can be built. Externally audited by Big Four $(B I G 4)$ is a control variable used similarly by OwensJackson et al. (2009), audit fee was another original control variable that was subsequently removed due to multicollinearity. This has resulted in hypothesis one through eleven looking at the significance of each on the likelihood of corporate scandal.

\section{Insert Table 1 about here}

\section{Results and Discussion}

\subsection{Descriptive Statistics}

Table 2 presents the descriptive statistics across the whole sample along with a breakdown of scandal (AEP) and no scandal firm statistics.

Table 2 presents some differences between the scandal and no scandal firms. It can be seen that scandal firms audit committees tend to be smaller, hold more meetings, have less gender diversity and are audited less by Big Four firms: $64 \%$ to no scandals $96 \%$. This would make it appear there is possibly be a resource issue in fraud firms, such as a link between size and diversity. As for their audit committee members, scandal firms tend to have less qualified accountants, which could also be linked to size, as well as greater outside directorships, receive a greater commission, hold greater shareholdings, and serve on the audit committee longer. Since scandal firms have greater shareholdings and longer tenures, it could be argued this is an agency threat in scandal firms. There was little difference in audit experience between scandal and no scandal at $16.36 \%$ and $15.83 \%$ respectively, which is surprising considering the difference in accountancy qualifications, as well as scandal firms having less qualified accountants. Audit committee meeting attendance was similar and very high for both. Looking 
at guidance set out in the UK Corporate Governance Code 2018, both scandal and no scandal audit committees meet in excess of the recommended 3 meetings at 4.5 and 4.07 , respectively. Furthermore, both scandal and no scandal audit committees are bigger than the recommended 3 members at 3.96 and 4.16 members, respectively. It can also be seen from the qualified accountant stats firms in both samples generally have 1 qualified accountant, which would be higher if this study had also included financial and supervisory qualified members to be counted. Overall, these figures are interesting because they suggest that both sets of firms, in terms of their audit committees, were on average compliant with the guidance of the UK Corporate Governance Code 2018 which opens up a debate as to whether the guidance is too loose.

Looking at the combined statistics of the whole sample compared to other UK studies average female audit committee membership of $30.69 \%$ is in line with Velte (2018), whose sample had an average of $24 \%$. These averages show a lack of diversity at the audit committee level. The audit committees in this sample were slightly larger and held slightly more meetings than some other UK studies (Ghafran and O'Sullivan, 2017; Li et al., 2012). Average audit committee accounting qualification is slightly lower than Beattie et al. (2012), but the mean former auditors is very similar at 0.65 members compared to their 0.6 members. The average shareholding of the sample $(0.4 \%)$ is lower than Ghafran and O'Sullivan (2017) average of 1.6\%; interestingly, this is higher than this paper's fraud sample too. The average outside directorships in this sample of 2.41 is significantly higher than Ghafran and O'Sullivan (2017) average of 0.35 . Each variable had 66 observations. The sample on average complied with the UK Corporate Governance Code 2018.

\section{Insert Table 2 about here}


The final correlations for variables used in the regression can be observed in Table 3. The highest correlation, 0.68 , is observed between audit committee meeting frequency and audit committee compensation. The only other correlation above 0.5 is the correlation between a qualified accountant and audit experience at 0.62 , which intuitively makes sense. These values are similar to previous studies such as Badolato et al. (2014) who had correlations of 0.654 and 0.633, whilst Ghafran and O'Sullivan (2017) had a correlation of 0.765 which shows these are a generally acceptable amount.

\section{Insert Table 2 about here}

\subsection{Regression Results}

\subsubsection{Audit committee gender diversity}

We examine whether more gender diversity on the audit committee is associated with the corporate scandal. The evidence is that across the board, females are underrepresented and there should be greater diversity since the average female representation being $30.7 \%$ with some committees in both AEP and non-AEP firms have no representation. There is approximately as many qualified accountants on a committee as females, an alarming comparison. In terms of regression results, this was looked at by female representation $\left(\mathrm{H}_{1}\right)$ and female chairperson representation $\left(\mathrm{H}_{2}\right)$ since this is the most senior and influential role on the committee. The results of the regression were that both hypotheses were rejected as both were found to be insignificant at 0.815 and 0.751 , respectively. The results are consistent with the findings of Chen et al. (2016) and Abbott et al. (2012) in that it is agreed that although there are benefits to females on the board, these benefits are not driven by audit committee representation. Sun et al. (2011) were also unable to identify an association between female audit representation and earnings management. It is possible that similarly to accountancy qualifications, the lack of representation among both samples means the benefits are being recognised or highlighted the way they should. The benefits of female attitudes such as being 
more risk-averse should have clear benefits, but unfortunately, these have yet to be realised in this context. However, Thiruvadi and Huang (2011) found female presence constrains earnings management, while Ittonen et al. (2010) results suggest a female chairperson reduces the risk of misstatement, common factors that lead to scandal. A reason for these differences could be the size of the firms in this paper's sample. To fall under the score of AEP and therefore, this sample, a firm must be a public interest entity or AIM-listed with a market capitalisation of over $€ 200$ million. This is important as larger firms tend to have significantly higher female representation on their audit committees as core members (Wilson, 2010; Zhu et al., 2010). Therefore, based on this, it comes as less of a surprise that it was not a significant factor. Although there is greater female representation in larger firms, females are still underrepresented, and this should be an area of considerable focus, there is greater diversity, it could prove to be a significant factor. This paper recommends that future versions of the UK Corporate Governance Code keep encouraging gender diversity and do more to highlight the benefits of it. It is not recommended that there is any forced requirement as that would be discriminatory towards other gender(s).

\subsubsection{Audit committee financial expertise}

It is recommended in the UK Corporate Governance Code 2018 that all audit committees should have at least one financially competent committee member. As the sample companies all follow the same code, it makes sense that it was unlikely the vague and generalised financial experience requirement would yield any significant results. For this reason, two commonly examined categories of financial expertise were used in accountancy qualifications $\left(\mathrm{H}_{3}\right)$ and previous audit experience $\left(\mathrm{H}_{3}\right)$. The results were that both were found to be insignificant at $\mathrm{p}=0.351$ and $\mathrm{p}=0.318$ respectively, and therefore, both are rejected, which is surprising. Intuitively it could be expected that these skills and experience would mitigate the likelihood of investigation. These results suggest that although there may be benefits to having accounting 
and audit experience on the committee to understand complex financial issues, these are not associated with the likelihood of FRC investigation. There is potential that an association with FRC investigations comes from supervisory expertise or general financial expertise. Furthermore, it should be noted that the coefficient for accounting experience was negative (3.17) which is evidence it could have a mitigating association, but the average percentage of members with accountancy qualifications is $29.1 \%$ and only $16 \%$ for audit experience. Therefore, it is possible that without a majority with such skills, decisions are taken out of their hands by majority rule.

These results are comparable to Appiah and Chizema (2017) and Owens-Jackson et al. (2009) who finds no significant relationship between having a financial expert on the audit committee and corporate insolvency or fraudulent financial reporting respectively. These results differ from Farber (2005) who find fraudulent firms tend to have fewer financial experts on their audit committee, a feature of this study as well in terms of accounting experience. Naiker and Sharma (2009) also find evidence as their findings suggest audit experience on the audit committee is associated with greater monitoring of internal controls and financial reporting. Greater monitoring of internal controls does not always translate into less likelihood of investigation since many of the actions that lead to sanctions are the result of management overrides. This study is limited in that it has not looked at two other areas of financial expertise; financial and supervisory, which can also be used to satisfy the 2018 UK Corporate Governance Code recommendation and could be studied in the future. The two chosen variables were specifically chosen due to previous literature and that they are a requirement of audit committees for financial services firms under the Financial Conduct Authority (FCA, 2020). Based on the results the UK Corporate Governance Code should consider following the requirements of the Financial Conduct Authority, however, this is not regarded as an urgent matter and there may be benefits to stability of the code in this area. 


\subsubsection{Audit committee member tenure}

The other significant independent variable identified by this paper was the average tenure of audit committee members. Audit Committee average tenure was the most significant variable $(p=0.021)$ of the regression and had a positive relationship with the likelihood of corporate scandal; therefore, $\mathrm{H}_{4}$ is accepted. This could be due to entrenchment that reduces effectiveness, or they defend policies that they supported in the past that are possibly not as applicable due to the rapidly changing business environment. As the changing business environment becomes more challenging, it may become increasingly more difficult for longertenured directors to keep ahead of changes to regulations and techniques that new members who bring fresh ideas to the committee could tackle. This result could also be linked to independence and suggest that the monitoring benefits of on-the-job experience are cancelled out by a familiarity threat. This threat is that over time longer-tenured members build friendly relationships with management that allows for undue influence in exercising independent judgement and having greater leniency with management. There is also the potential that with longer tenure it can be expected that members are to be more senior and in the latter part of their non-executive director career, which could come with greater risk appetite and less concern for reputation damage (Srinivasan, 2005). This evidence is again consistent with Kim et al. (2013) and Sharma and Iselin (2012) who find a positive and significant association between average audit committee member tenure and financial reporting violations and misstatements respectively.

Further to this Ghosh et al. (2010) and He and Yang (2014) find a significant and positive relationship between average tenure and earnings management, which supports calls for a restrictive limit on director tenure (Sharma and Iselin, 2012). This comes from a logical inconsistency for listed entities between what is considered optimal to maintain the key audit 
partner $^{11}$ independence and what is considered optimal for the audit committee that oversees them. The key audit partner is required to rotate every 5 years due by the FRC due to fear of their independence being compromised, so an independent audit committee should require the same (FRC, 2016b). This point is important as the average tenure among AEP firms was in excess of this at 5.7 years with some as members tenure as high as 11 years, making a strong case for these committees losing their independence and therefore damaging their objectivity and monitoring ability. For comparison, Non-AEP firm's average tenures were comfortably within this at 3.79 years, so this is possibly an area of future study. There is some contradicting empirical literature in this area, as Owens-Jackson et al. (2009) find no significant relationship between committee tenure and fraudulent financial reporting. While Yang and Krishnan (2005) find tenure to be negatively related to earnings management which would suggest the experience has positive effects, however Garven (2015) and Sun et al. (2014) find no relationship for the same metric. The differences in results between this paper and OwensJackson et al. (2009) may be down to the difference US and UKs litigation landscapes, which arguably in the US keep members more in line. This paper calls for consistency by regulators in what is necessary for maintaining independence, as the current differing requirements between independent key audit partners and audit committee members in nonsensical.

\subsubsection{Audit committee independence}

Audit committee independence is now largely a requirement in most developed corporate government systems now. It has been widely studied and the positive impacts of the characters are well documented. For this reason, this paper looked at factors which could compromise audit committee independence, such as excessive audit committee remuneration and excessive audit committee share ownership. Based on the results, both hypotheses are rejected as their pvalues of 0.422 and 0.646 show they are insignificant and are not associated with the likelihood

\footnotetext{
${ }^{11}$ For an audit, the engagement partner is a key audit partner.
} 
of corporate scandal. These results suggest that in this study independence is not breached to a problematic extent by remuneration or share ownership but that it also has little enhancing benefits either. The result is supported by Persons (2012) as they find no significant association between fraudulent financial reporting and cash remuneration levels.

\subsubsection{Audit committee share ownership}

The lack of significance in share ownership is likely down to low shareholdings on average across both AEP and non-AEP firms because the coefficient is highly positive (34.12) which would suggest at higher levels this may be detrimental. This is supportive evidence that at higher levels of shareholding, a member's independence could be compromised due to their financial interest in the firm. There is weak support for this result by Garven (2015) and Ghosh et al. (2010) who find no evidence to suggest audit committee share ownership is associated with earnings management. This is weak evidence as aggressive earnings management can commonly lead to sanctions, for example, Carillion (one of the sample companies). There are many other ways, however, that companies may find themselves under investigation by a regulator.

Contrary to this finding, Uzun et al. (2004) find that a higher degree of independence in the audit committee significantly reduces the likelihood of fraud. Their paper analysed member relationships with management as well as some other factors to determine the degree of independence. This is likely why share ownership had such a high coefficient as it is a factor in determining the degree of independence of an audit committee. Abbott et al. (2000) and Owens-Jackson et al. (2009) also find independence to be a key driver. It is important to note independence may be determined through other factors than member remuneration and share 
ownership ${ }^{12}$. It may be a limitation of this study that all independence factors could not be considered. Based on the findings above this paper does not recommend any restrictions or a cap on audit committee member remuneration as long as it is not tied to performance. Further to this, the highly positive coefficient of shareholding percentage would suggest that the regulator should consider a limit on member equity holdings of the firm since the maximum held was $12.94 \%$ in this sample.

\subsubsection{Audit committee size}

The provision for size in the UK Corporate Governance Code 2018 is that it must be satisfied with at least 3 members, or in smaller companies $2^{13}$. In analysing this variable, it helps regulators understand both if the minimum is the right amount and if too little or too many members is associated with the likelihood of FRC investigation. The result of the regression analysis is that size is not significant and $\mathrm{H}_{8}$ is, therefore, rejected at a p-value of 0.594 . This is consistent with Farber (2005) who found audit committee size to have no significance in the likelihood of SEC sanctions, while other studies complement this view as well (Agrawal and Chadha., 2005; Appiah and Chizema, 2017; Hoitash et al., 2009). Wilbanks et al. (2017) and Sharma and Iselin (2012) however find that audit committee size is significant and positively associated to enhanced risk monitoring of fraud. The characteristic is likely insignificant because on average, both AEP and non-AEP firms were more than the UK requirement at 3.95 and 4.15 members, respectively. Therefore, it could be that the minimum requirement helps reduce the likelihood of corporate scandal, but this has diminishing returns, and although there may be group benefits to a larger audit committee, this influence is limited if the base requirements are met. It may also be that size has indirect benefits such as with growth could

\footnotetext{
${ }^{12}$ Other factors used to determine independence are: not an employee in the last 5 years, no business relationship in the last 3 years, has not received performance related pay, no family ties, and has not served on the board for over 9 years from their first appointment.

${ }^{13}$ Defined in the UK Corporate Governance Code (2018) as companies below the FTSE 350 index.
} 
come greater variety of skills and gender, as well as more independent or non-independent members.

\subsubsection{Audit committee activity}

The first significant variable of this study is audit committee activity which through the number of audit committee meeting frequency $\left(\mathrm{H}_{9}\right)$ was found to have a significant and positive relationship with the likelihood of corporate scandal at the $10 \%$ level, therefore $\mathrm{H}_{9}$ is accepted. This result suggests that companies who are having, or on the verge, of corporate scandal either currently or in the previous year - have a higher frequency of audit committee meetings. A reason for this could be that the companies recognise the problems and are meeting more in an attempt to address the issues that are leading to the scandal. This is consistent with the findings of Sharma and Iselin (2012) who find a significant relationship between meeting frequency and financial misstatement. However, there is consistent evidence to suggest meeting frequency reduces the likelihood of financial fraud by Abbott et al. (2000), Farber (2005), and Owens-Jackson et al. (2009). This could be a paradox in that both may be true. For example, some companies may meet more to try and be more effective since this could be viewed as a sign of diligence whereas other companies meet more because of problems, therefore depending on the sample both these conflicting arguments could be true at the same time. Another reason for the differences in results is the different regulatory requirements over the time periods. Abbott et al. (2000) and Farber (2005) are both pre-SOX where there was no requirement for meetings, Farber (2005) average meeting frequency for both fraud and nofraud firms were under 2 meetings. For the latter study, SOX requires by law that audit committees now meet at least 4 times per year compared to the UK Corporate Governance Codes of 2014 and 2018 recommendations of a minimum of 3 meetings. This enforcement of 4 naturally leads to greater meetings in general and encourages meeting more than a lower recommendation would. It should also be considered that the AEP firms were meeting more, 
4.5 times, in an attempt to follow best practice and legitimise themselves when there were issues so it is worth considering that an increase in the recommendation would result in similar patterns. On this same point of legitimacy, the maximum number of meetings for AEP firms was 9 times which raises questions on the content of the meetings. It is highly possible that many of these meetings lacked substance and were purely ceremonial; unfortunately, the length and content of such meeting is not public knowledge.

The second part to activity is the attendance at the audit committee meetings $\left(\mathrm{H}_{10}\right)$. This was found to be insignificant, which is likely due to both samples on average having significantly high attendance $(>94 \%)$ at the meetings. Therefore $\mathrm{H}_{10}$ is rejected. It comes as no surprise though that the attendance of meetings had a negative coefficient as, without high attendance, it would be difficult to consider the viewpoints of all members. The result of this paper by no means suggests that meeting more has a direct causation effect on the likelihood of corporate scandal, only that it has a significant association. Therefore it is recommended that the UK Corporate Governance Code follows SOX and increases the recommendation to 4 meetings per year, as if companies meet more and are more diligent in the first place there may not be a requirement to meet more as issues relating to scandal arise since they will not exist.

\subsubsection{Audit committee other directorships}

There is currently no guidance in the UK Corporate Governance Code 2018 around the maximum number of other directorships that any one member may hold, only that the role can be time-consuming and that members should be aware of this when accepting a role. The average number of outside directorships $\left(\mathrm{H}_{11}\right)$ was found to be insignificant on the likelihood of corporate scandal. This result suggests that if some members have extra directorships, they are either doing so within their limits, so their time is not being spread too thinly, or other audit committee members are doing enough in their place to avoid negative consequences. This is consistent with the findings of Owens-Jackson et al. (2009), who also documented no 
significance in a similar study. Krishnan (2005) also supports this as they found no significance between additional directorships and internal control problems, which in many instances leads to situations of corporate scandal. It was expected that other directorships would either positively impact the committee as the member would bring experience from other committees which could help solve difficult challenges, or it would negatively impact the time by consuming too much of the members' time. The coefficient for other directorships was subsequently positive and although insignificant this is weak evidence to suggest too many other directorships could be damaging. The average number of directorships in this sample was 2.4, but some members had as many as five, which could reasonably be expected to be demanding.

Interestingly many other studies find additional directorships to be significant across some related factors. Sharma and Iselin (2012) found a positive association between additional directorships and financial misstatements, while Garven (2015) and Sun et al. (2014) link additional directorships to earnings management. On the flip side, Bedard et al. (2004) and Yang and Krishnan (2005) found a negative relationship between additional directors and earnings management. This is another area where there is inconsistent evidence in results, which may come from the variation in hours spent on each committee, for instance, it was shown in section 2.7 that audit committee members spent anywhere between less than 50 hours to over 150 on the committee. Therefore, at one extreme a member could have five other directorships but spend up 250 hours across them all. In contrast, at the other extreme, a member could have two other directorships that require over 400 hours of commitment. However, based on this study other directorships do not seem to be significantly associated with FRC investigations and therefore calls to implement any restrictions on the number of additional directorships a member may hold should be rejected (Sharma and Iselin, 2012). 


\subsubsection{Big 4 auditor}

One of the control variables that turned out to be significant at the $10 \%$ level with a p-value of 0.062 was the impact of the big 4. This was also found to be significant by Farber (2005), while Owens-Jackson et al. (2009) provided weak evidence of this in similar studies. This comes as no surprise since larger audit firms are argued to give higher quality audits (Astami et al., 2017; BenYoussef \& Drira, 2020; Bhuiyan \& D'Costa, 2020; Chan et al., 2020; Elamer, 2018b, 2018a; El-Dyasty \& Elamer, 2021; Eshleman and Guo, 2014; Gerged et al., 2020; Ji et al., 2015; Nuskiya et al., 2021; Owusu et al., 2020; Zeng et al., 2020). Further to this, Sundgren and Svanstrom (2013) argue smaller audit firms receive more sanctions due to poorer audit quality which coincides with the results above.

\section{Insert Table 4 about here}

\subsection{Endogeneity}

Our results so far suggest that the characteristics of an audit committee might mitigate the likelihood of corporate fraud/scandal/sanctions. Though, our main variable in this paper may be suffering from endogeneity. To handle this issue and self-selection bias (Abdelfattah et al., 2020), we apply the two-stage Heckman model (Heckman, 1979). We employ a probit regression model in the first stage of the two-stage Heckman model, where we use ownership concentration and board of directors' size as instruments to estimate the impact of self-selection bias on the choice of females. The dependent variable, the female audit committee chair, is a dummy variable. We then calculated the inverse Mills ratio $(\lambda)$ from the first stage that will measure the consequences of the self-selection bias. In the second stage, we use the fitted value of the female audit committee chair from the first stage.

Table 4 presents the results of the Heckman model. The results are similar to those considered above after including the Inverse-Mills ratio, $\lambda$, as an explanatory variable to uncover self- 
selection bias. After considering potential endogeneity, the characteristics of an audit committee still mitigate the likelihood of corporate fraud/scandal/sanctions These results show that our main results are robust.

\section{Conclusion}

This paper set out to analyse and understand the association between audit committee characteristics and the likelihood of corporate scandal, as defined by FRC investigation. Results based on the logit regression suggest that audit member tenure and audit committee meeting frequency both have positive associations to corporate scandal. It is suggested that at longer tenure lengths, audit committee members begin to lose their independence and their value has diminishing returns in the rapidly evolving business landscape. It is also suggested audit committees are more reactive than proactive to issues and may meet more frequently in an attempt to legitimise themselves. Other variables generally had the expected direction even if not significant. It was interesting that neither accountancy qualifications nor female representation had a significant influence; however, these variables did highlight the underrepresentation of both on audit committees.

These results should help regulatory policymakers make decisions which could be crucial to future corporate governance. Additionally, these results should be useful to investors who use corporate governance as criteria for investment decisions. It is recommended that the next UK regulator, which will likely be accompanied with a new code, should consider increasing the minimum requirement of yearly audit committee meetings to help mitigate the need for reactive meetings. It is also recommended that there should be consistent with what is deemed independent for one party and what is deemed independent for another. A final recommendation is that future versions of the UK Corporate Governance Code should continue to encourage diversity. These changes are incredibly important as high-profile corporate scandals undermine the integrity, quality, reliability, and transparent financial reporting, which 
brings into question the integrity and objectivity of both the accounting profession and the audit committee.

This paper had the following limitations. The first limitation is the small sample size, although where possible all available companies were used. This small sample was due to the availability of information. The FRC has been generally lenient with investigations which were shown from the two example papers that had similar parameters in the UK. The second limitation is in terms of audit committee meetings, as each company's individual meeting process is not publicly available. Ideally, it would have been insightful to understand the length and content of each meeting for a deeper understanding. The final limitation is the variety of variables used for each characteristic. Outstandingly, this paper would have looked at several other proxies for independence, such as family ties, as well as other proxies for financial expertise, such as governance expertise. Looking at any scope for future study, as the regulatory landscape is constantly changing, there will be new areas that require insight. For instance, the recent block on non-audit services by audit firms offer scope and opportunity to analyse the level of nonaudit service fees against audit committee characteristics. It may also be worth looking at all four US categories of financial expert in a UK context. A final recommendation for future study is greater analysis of females on the audit committee. 


\section{References}

Abbott, L.J., Park, Y., and Parker, S. (2000) 'The effects of audit committee activity and independence on corporate fraud', Managerial Finance, 26:11, 55-83.

Abbott, L.J., Parker, S., and Peters, G.F. (2004) 'Audit Committee Characteristics and Restatements', Auditing, 23:1, 69-87.

Abbott, L.J., Parker, S., and Presley, T.J. (2012) 'Female board presence and the likelihood of financial restatement', Accounting Horizons, 26:4, 607-629.

Abdelfattah, T., Elmahgoub, M. \& Elamer, A.A. (2020). Female Audit Partners and Extended Audit Reporting: UK Evidence. Journal of Business Ethics. Forthcoming. https://doi.org/10.1007/s10551-020-04607-0

Abernathy, J.L., Beyer, B., Masli, A., and Stefaniak, C. (2014) 'The association between characteristics of audit committee accounting experts, audit committee chairs, and financial reporting timeliness', Advances in Accounting, 30:2, 283-297.

Agrawal, A., and Chadha, S. (2005) 'Corporate Governance and Accounting Scandals', The Journal of Law \& Economics, 48:2, 371-406.

Agyemang-Mintah, P., \& Schadewitz, H. (2018). Audit committee adoption and firm value: evidence from UK financial institutions. International Journal of Accounting and Information Management, 26(1), 205226.

Agyemang-Mintah, P., \& Schadewitz, H. (2019). Gender diversity and firm value: evidence from UK financial institutions. International Journal of Accounting and Information Management, 27(1), 2-26.

Albitar, K., Gerged, A. M., Kikhia, H., \& Hussainey, K. (2020a). Auditing in times of social distancing: the effect of COVID-19 on auditing quality. International Journal of Accounting and Information Management, 29(1), 169-178.

Albitar, K., Hussainey, K., Kolade, N., \& Gerged, A. M. (2020b). ESG disclosure and firm performance before and after IR: The moderating role of governance mechanisms. International Journal of Accounting and Information Management, 28(3), 429-444.

AlHares, A., Elamer, A. A., Alshbili, I., \& Moustafa, M. W. (2020). Board structure and corporate R\&D intensity: evidence from Forbes global 2000. International Journal of Accounting and Information Management, 28(3), 445-463.

Alnabsha, A., Abdou, H. A., Ntim, C. G., \& Elamer, A. A. (2018). Corporate boards, ownership structures and corporate disclosures: Evidence from a developing country. Journal of Applied Accounting Research, $19(1), 20-41$

Al-Najjar, B. (2011) 'The Determinants of Audit Committee Independence and Activity: Evidence from the UK', International Journal of Auditing, 15:2, 191-203.

Alshbili, I., \& Elamer, A. A. (2019). The influence of institutional context on corporate social responsibility disclosure: a case of a developing country. Journal of Sustainable Finance \& Investment, 0, 1-25. 
Alshbili, I., Elamer, A. A., \& Beddewela, E. (2019). Ownership types, corporate governance and corporate social responsibility disclosures: Empirical evidence from a developing country. Accounting Research Journal, Forthcoming. https://doi.org/10.1108/ARJ-03-2018-0060

Appiah, K.O., and Chizema, A. (2017) 'Board audit committee and corporate insolvency', Journal of Applied Accounting Research, 18:3, 298-316.

Archambeault, D.S., Dezoort, F.T., and Hermanson, D.R. (2008) 'Audit Committee Incentive Compensation and Accounting Restatements, Contemporary Accounting Research, 25:4, 965-992

Astami, E. W., Rusmin, R., Hartadi, B., \& Evans, J. (2017). The role of audit quality and culture influence on earnings management in companies with excessive free cash flow: Evidence from the Asia-Pacific region. International Journal of Accounting and Information Management, 25(1), 21-42.

Badolato, P.G., Donelson, D.C., and Ege, M. (2014) 'Audit committee financial expertise and earnings management: The role of status', Journal of Accounting and Economics, 58:2-3, 208-230.

Barrier, M. (2002) 'The compensation balance', The Internal Auditor, 59:3, 42-47.

Beasley, M.S., Carcello, J.V., Hermanson, D.R., and Neal, T.L. (2009) 'The audit committee oversight process', Contemporary Accounting Research, 26:1, 65-122.

Beattie, V., Fearnley, S., and Hines, T. (2012) 'Do UK audit committees really engage with auditors on audit planning and performance?', Accounting and Business Research, 42:3, 349-375.

Bedard, J., Chtourou, S.M., Courteau, L. (2004) 'The Effect of Audit Committee Expertise, Independence, and Activity on Aggressive Earnings Management', Auditing: A Journal of Practice \& Theory, 23:2, 1335.

BenYoussef, N., \& Drira, M. (2020). Auditor monitoring and restatement dark period. International Journal of Accounting and Information Management, 28(1), 73-95.

Bhuiyan, M. B. U., \& D'Costa, M. (2020). Audit committee ownership and audit report lag: evidence from Australia. International Journal of Accounting and Information Management, 28(1), 96-125.

Blalock Jr, HM (1963) 'Correlated independent variables: The problem of multicollinearity', Social Forces, 42:2, 233-237.

Brooks, R., 2018. Bean counters: The triumph of the accountants and how they broke capitalism. Atlantic Books.

Bufarwa, I. M., Elamer, A. A., Ntim, C. G., \& AlHares, A. (2020). Gender diversity, corporate governance and financial risk disclosure in the UK. International Journal of Law and Management, 62(6), 521-538.

Burrell, G., and Morgan, G (1979) Sociological Paradigms and Organisational Analysis: elements of the Sociology of Corporate Life. Heinemann Educational books.

Campbell, J.L., Hansen, J., Simon, C.A., and Smith, J.L. (2015) 'Audit Committee Stock Options and Financial Reporting Quality after the Sarbanes-Oxley Act of 2002', Auditing: A Journal of Practice \& Theory, 34:2, 91-120.

Carcello, J.V., and Neal, T.L. (2000) 'Audit Committee Composition and Auditor Reporting', The Accounting Review, 75:4, 453-467. 
Carcello, J.V., and Neal, T.L. (2003) 'Audit committee characteristics and auditor dismissals following 'new' going-concern reports', Accounting Review, 78:1, 95-118.

Chan, S. H., Creel, T. S., Song, Q., \& Yurova, Y. v. (2020). Does CSR reporting indicate strong corporate governance? International Journal of Accounting and Information Management, 29(1), 27-42.

Chen, Y., Eshleman, J.D., and Soileau, J.S. (2016) 'Board gender diversity and internal control weaknesses', Advances in accounting, 33, 11-19.

Elamer, A. A., \& Benyazid, I. (2018). The impact of risk committee on financial performance of UK financial institutions. International Journal of Accounting and Finance, 8(2), 161-180.

Elamer, A. A., AlHares, A., Ntim, C. G., \& Benyazid, I. (2018). The corporate governance-risk-taking nexus: evidence from insurance companies. International Journal of Ethics and Systems, 34(4), 493-509.

Elamer, A. A., Ntim, C. G., \& Abdou, H. A. (2020). Islamic Governance, National Governance, and Bank Risk Management and Disclosure in MENA Countries. Business and Society, 59(5), 914-955.

Elamer, A. A., Ntim, C. G., Abdou, H. A., \& Pyke, C. (2019). Sharia supervisory boards, governance structures and operational risk disclosures: Evidence from Islamic banks in MENA countries. Global Finance Journal, 100488.

Elamer, A. A., Ntim, C. G., Abdou, H. A., Zalata, A. M., \& Elmagrhi, M. H. (2019). The impact of multi-layer governance on bank risk disclosure in emerging markets: the case of Middle East and North Africa. Accounting Forum, 43(2), 246-281.

El-Dyasty, M. M., \& Elamer, A. A. (2020). The effect of auditor type on audit quality in emerging markets: evidence from Egypt. International Journal of Accounting and Information Management, 29(1), 4366.

El-Dyasty, M. M., \& Elamer, A. A. (2021). The effect of ownership structure and board characteristics on auditor choice: evidence from Egypt. International Journal of Disclosure and Governance, 1-16.

Elmagrhi, M. H., Ntim, C. G., Crossley, R. M., Malagila, J. K., Fosu, S., \& Vu, T. v. (2017). Corporate governance and dividend pay-out policy in UK listed SMEs: The effects of corporate board characteristics. International Journal of Accounting and Information Management, 25(4), 459-483.

Elmagrhi, M. H., Ntim, C. G., Elamer, A. A., \& Zhang, Q. (2018). A study of environmental policies and regulations, governance structures, and environmental performance: the role of female directors. Business Strategy and the Environment, 28(1), 206-220.

Engel, E., Hayes, R.M., and Wang, X. (2010) 'Audit committee compensation and the demand for monitoring of the financial reporting process', Journal of Accounting and Economics, 49:1, 136-154

Enriques, L. (2003) 'Bad apples, bad oranges: comment from old Europe on post-enron corporate governance reforms', Wake Forrest Law Review, 38:3, 911-934.

Eshleman, J.D., and Guo, P. (2014) 'Do Big 4 auditors provide higher audit quality after controlling for the endogenous choice of auditor?', Auditing: A Journal of Practice \& Theory, 33:4, 197-219.

Farber, D.B. (2005) 'Restoring trust after fraud: does corporate governance matter?', Accounting Review, 80:2, 539-561. 
Feng, Y., Hassan, A., \& Elamer, A. A. (2020). Corporate governance, ownership structure and capital structure: evidence from Chinese real estate listed companies. International Journal of Accounting and Information Management, 28(4), 759-783.

Ferreira, I. (2008) 'The effect of audit committee composition and structure on the performance of audit committees', Meditari Accountancy Research, 16:2, 89-106.

Financial Conduct Authority (2020) 'DTR 7.1 Audit committees'. [Accessed 10/3/20] Available from $<$ https://www.handbook.fca.org.uk/handbook/DTR/7/1.html> .

Financial Reporting Council (2016a) 'Guidance on Audit Committees'. [Accessed 27/12/19] Available from: <https://www.frc.org.uk/getattachment/6b0ace1d-1d70-4678-9c41-0b44a62f0a0d/Guidance-onAudit-Committees-April-2016.pdf $>$.

Financial Reporting Council (2016b) 'Revised Ethical Standard 2016'. [Accessed: 20/1/2020] Available from $<$ https://www.frc.org.uk/getattachment/0bd6ee4e-075c-4b55-a4ad-b8e5037b56c6/Revised-EthicalStandard-2016-UK.pdf>

Financial Reporting Council (2018) 'THE UK CORPORATE GOVERNANCE CODE'. [Accessed: 27/12/2019] Available from: <https://www.frc.org.uk/getattachment/88bd8c45-50ea-4841-95b0d2f4f48069a2/2018-UK-Corporate-Governance-Code-FINAL.pdf>

Garven, S. (2015) 'The effects of board and audit committee characteristics on real earnings management: do boards and audit committees play a role in its promotion or constraint?', Academy of Accounting and Financial Studies Journal, 19:1, 67-85.

Gavious, I., Segev, E., and Yosef, R. (2012) 'Female directors and earnings management in high-technology firms', Pacific Accounting Review, 24:1, 4-32

Gerged, A. M., Al-Haddad, L. M., \& Al-Hajri, M. O. (2020). Is earnings management associated with corporate environmental disclosure? Evidence from Kuwaiti listed firms. Accounting Research Journal, 33(1), $167-185$.

Ghafran, C., and O'Sullivan, N. (2017) 'The impact of audit committee expertise on audit quality: Evidence from UK audit fees', The British Accounting Review, 49:6, 578-593.

Ghosh, A., Marra, A., and Moon, D. (2010) 'Corporate Boards, Audit Committees, and Earnings Management: Pre- and Post-SOX Evidence', Journal of Business Finance \& Accounting, 37:9-10, 1145-1176.

Habbash, M., Sindezingue, C., and Salama, A. (2013) 'The effect of audit committee characteristics on earnings management: Evidence from the United Kingdom', International Journal of Disclosure and Governance, 10:1, 13-38.

Harjoto, M.A., Laksmana, I., and Lee, R. (2015) 'The impact of demographic characteristics of CEOs and directors on audit fees and audit delay', Managerial Auditing Journal, 30:8/9. 963-997

Harrast, S.A., and Mason-Olsen, L. (2007) 'Can Audit Committees Prevent Management Fraud?', The CPA Journal, 77:1, 24-27.

He, L., and Yang, R. (2014) 'Does industry regulation matter? New evidence on audit committees and earnings management', Journal of Business Ethics, 123:4, 573-589. 
Hoitash, U., Hoitash, R., and Bedard, J.C. (2009) 'Corporate Governance and Internal Control over Financial Reporting: A Comparison of Regulatory Regimes', The Accounting Review, 84:3, 839-867.

Huang, H.W., and Thiruvadi, S. (2010) 'Audit committee characteristics and corporate fraud', International Journal of Public Information Systems, 6:1, 71-82.

Ittonen, K., Miettinen, J., and Vähämaa, S. (2010) 'Does female representation on audit committees affect audit fees?', Quarterly Journal of Finance and Accounting, 49:3/4, 113-139.

Ji, X. D., Ahmed, K., \& Lu, W. (2015). The impact of corporate governance and ownership structure reforms on earnings quality in China. International Journal of Accounting and Information Management, 23(2), 169-198.

Kaplan, S., Pany, K., Samuels, J. and Zhang, J. (2009), 'An examination of the association between gender and reporting intentions for fraudulent financial reporting', Journal of Business Ethics, 87:1, 15-30

Karim, A. K. M. W., Zijl, T. van, \& Mollah, S. (2013). Impact of board ownership, CEO-Chair duality and foreign equity participation on auditor quality choice of IPO companies: Evidence from an emerging market. International Journal of Accounting and Information Management, 21(2), 148-169.

Kelton, A.S., and Yang, Y. (2008) 'The impact of corporate governance on Internet financial reporting', Journal of Accounting and Public Policy, 27:1, 62-87.

Khatib, S. F. A., Abdullah, D. F., Elamer, A. A., \& Abueid, R. (2021). Nudging toward diversity in the boardroom: A systematic literature review of board diversity of financial institutions. Business Strategy and the Environment, 30(2), 985-1002.

Kim, J.Y., Roden, D.M. and Cox, S.R. (2013) 'The composition and compensation of the board of directors as predictors of corporate fraud', Accounting and Finance Research, 2:3, 142-154.

Klein, A. (2002) 'Audit committee, board of director characteristics, and earnings management', Journal of Accounting and Economics, 33:3, 375-400.

Krishnan, J. (2005) ‘Audit Committee Quality and Internal Control: An Empirical Analysis', The Accounting Review, 80:2, 649-675.

Li, J., Mangena, M., and Pike, R. (2012) 'The effect of audit committee characteristics on intellectual capital disclosure', The British Accounting Review, 44:2, 98-110.

Li, M., \& Song, L. (2018). Corporate governance, accounting information environment and investment-cash flow sensitivity. International Journal of Accounting and Information Management, 26(4), 492-507.

Liu, G., and Sun, J. (2010) 'Director tenure and independent audit committee effectiveness', International Research Journal of Finance and Economics, 51, 176-189.

MacGregor, J. (2012) 'Audit committee equity holdings, the risk of reporting problems, and the achievement of earnings thresholds', Journal of Accounting and Public Policy, 31:5, 471-491.

Madi, H.K., Ishak, Z., and Manaf, N.A.A. (2014) 'The Impact of Audit Committee Characteristics on Corporate Voluntary Disclosure', Procedia - Social and Behavioral Sciences, 164, 468-492.

Magilke, M.J, Mayhew, B.M., and Pike, JE (2009) 'Are Independent Audit Committee Members Objective? Experimental Evidence', The Accounting Review, 84:6, 1959-1981 
Mangena, M., and Pike, R. (2005) 'The effect of audit committee shareholding, financial expertise and size on interim financial disclosures', Accounting and Business Research, 35:4, 327-349.

McGrane, B.A. (2009) 'The audit committee: director liability in the wake of the Sarbanes-Oxley Act and Tello v. Dean Witter Reynolds', Cornell Journal of Law and Public Policy, 18:2, 575-608.

Morgan, G., and Smircich, L (1980) 'The Case for Qualitative Research', The Academy of Management Review, 5 (4), 491-500.

Naiker, V., and Sharma, D.S. (2009) 'Former audit partners on the audit committee and internal control deficiencies', The Accounting Review, 84:2, 559-587.

Nuskiya, M. N. F., Ekanayake, A., Beddewela, E., \& Meftah Gerged, A. (2021). Determinants of corporate environmental disclosures in Sri Lanka: the role of corporate governance. Journal of Accounting in Emerging Economies, 11(3), 367-394.

Owens-Jackson, L.A., Robinson, D., and Shelton, S.W. (2009) 'The Association Between Audit Committee Characteristics, the Contracting Process and Fraudulent Financial Reporting', American Journal of Business, 24:1, 57-65.

Owusu, A., Zalata, A. M., Omoteso, K., \& Elamer, A. A. (2020). Is There a Trade-Off Between Accrual-Based and Real Earnings Management Activities in the Presence of (fe) Male Auditors? Journal of Business Ethics, 1, 3. https://doi.org/10.1007/s10551-020-04672-5

Parker, R.J., Dao, M., Huang, H.W., and Yan, Y.C. (2017) 'Disclosing material weakness in internal controls: Does the gender of audit committee members matter?', Asia-Pacific Journal of Accounting \& Economics, 24:3/4, 407-420.

Peasnell, K.V., Pope, PF, and Young, S. (2001) 'The characteristics of firms subject to adverse rulings by the Financial Reporting Review Panel', Accounting and Business Research, 31:4, 291-311

Persons, O.S. (2009) 'Audit committee characteristics and earlier voluntary ethics disclosure among fraud and no-fraud firms', International Journal of Disclosure and Governance, 6:4, 284-297.

Persons, O.S. (2012) 'Stock Option and Cash Compensation of Independent Directors and Likelihood of Fraudulent Financial Reporting', The Journal of Business and Economic Studies, 18:1, 54-74.

Rickling, M.F., and Sharma, D.S. (2017) 'Audit committee cash compensation and propensity of firms to beat earnings by a large margin: Conditional effects of CEO power and agency risks', International Journal of Auditing, 21:3, 304-323

Roden, D.M., Cox, S.R., and Kim, J.Y. (2016) 'The fraud triangle as a predictor of corporate fraud', Academy of Accounting and Financial Studies, 20:1, 80-92.

Rupley, K., Almer, E. and Philbrick, D. (2011) 'Audit committee effectiveness: Perceptions of public company audit committee members post-SOX', Research in Accounting Regulation, 23:2, 138-144.

Ryan, B., Scapens, R.W., and M. Theobald (2002) Research Method and Methodology in Finance and Accounting. 2nd Edition. Thomson: London.

Sharma, V.D., and Iselin, E.R. (2012) 'The association between audit committee multiple-directorships, tenure, and financial misstatements', Auditing: A Journal of Practice \& Theory, 31:3, 149-175. 
Song, J., and Windram, B. (2004) 'Benchmarking Audit Committee Effectiveness in Financial Reporting', International Journal of Auditing, 8:3, 195-205.

Srinivasan, S. (2005) 'Consequences of financial reporting failure for outside directors: Evidence from accounting restatements and audit committee members', Journal of Accounting Research, 43:2, 291334.

Sun, J., Lan, G., and Liu, G. (2014) 'Independent audit committee characteristics and real earnings management', Managerial Auditing Journal, 29:2, 153-172.

Sun, J., Liu, G., and Lan, G. (2011) 'Does female directorship on independent audit committees constrain earnings management?', Journal of Business Ethics, 99:3, 369-382.

Sundgren, S., and Svanstrom, T. (2012) 'Audit office size, audit quality and audit pricing: evidence from smalland medium-sized enterprises', Accounting and Business Research, 43:1, 31-55.

Thiruvadi, S., and Huang, H.W. (2011) 'Audit committee gender differences and earnings management', Gender in Management, 26:7, 483-498.

Thompson, C. (2003) 'Willful Blindness', The Internal Auditor, 60:3, 71-73.

Uzun, H., Szewczyk, S.H., and Varma, R. (2004) 'Board Composition and Corporate Fraud', Financial Analysts Journal, 60:3, 33-43.

Vafeas, N. (2003) 'Length of Board Tenure and Outside Director Independence', Journal of Business Finance \& Accounting, 30:7/8, 1043-1064.

Vafeas, N. (2005) 'Audit Committees, Boards, and the Quality of Reported Earnings*', Contemporary Accounting Research, 22:4, 1093-1122.

Velte, P. (2018) 'Does gender diversity in the audit committee influence key audit matters' readability in the audit report? UK evidence', Corporate Social Responsibility and Environmental Management, 25:5, 748-755.

Vermeir, I., and Van Kenhove, P. (2007), 'Gender differences in double standards', Journal of Business Ethics, $81: 2,281-95$.

Wilbanks, R.M., Hermanson, D.R., and Sharma, V.D. (2017) 'Audit Committee Oversight of Fraud Risk: The Role of Social Ties, Professional Ties, and Governance Characteristics', Accounting Horizons, 31:3, 21-39

Wilson, J. and Thomas, E. (2010) 'Females and financial experts: board diversity in the ERA of the SEC's audit committee requirements', Academy of Accounting \& Financial Studies Journal, 14:4, 1-10.

Wu, C.Y., Hsu, H., and Haslam, J. (2016) ‘Audit committees, non-audit services, and auditor reporting decisions prior to failure', The British Accounting Review, 48:2, 240-256.

Yang, J.S., and Krishnan, J. (2005) 'Audit Committees and Quarterly Earnings Management', International Journal of Auditing, 9:3, 201-219.

Yu, M., \& Wang, Y. (2018). Firm-specific corporate governance and analysts' earnings forecast characteristics: Evidence from Asian stock markets. International Journal of Accounting and Information Management, 26(3), 335-361. 
Zeng, H., Yang, L., \& Shi, J. (2020). Does the supervisory ability of internal audit executives affect the occurrence of corporate fraud? Evidence from small and medium-sized listed enterprises in China. International Journal of Accounting and Information Management, 29(1), 1-26.

Zhang, Y., Zhou, J., and Zhou, N. (2007) 'Audit committee quality, auditor independence, and internal control weaknesses', Journal of Accounting and Public Policy, 26:3, 300-327.

Zhu, H., Small, K., and Flaherty, S. (2010) 'An Examination of Female Participation on US Board Subcommittees', Journal of Business \& Management, 16:2, 153-191. 


\section{Tables}

Table 1: Variables description

\begin{tabular}{|c|c|c|}
\hline Name & Abbreviation & Description \\
\hline \multicolumn{3}{|c|}{ Dependent Variable } \\
\hline Scandal & Scandal & $1=$ AEP company. $0=$ Otherwise \\
\hline \multicolumn{3}{|c|}{ Independent Variables } \\
\hline Female Chair & $\mathrm{ACFC}$ & Percentage of chairpersons that were female. \\
\hline $\begin{array}{l}\text { Female audit } \\
\text { committee }\end{array}$ & $\mathrm{ACF}$ & Percentage of audit committee members that were female. \\
\hline Qualified & ACQ & Percentage of audit committee members that held a Chartered \\
\hline Accountant & & Accountancy qualification. \\
\hline $\begin{array}{l}\text { No. of } \mathrm{AC} \\
\text { meetings }\end{array}$ & $\mathrm{ACM}$ & $\begin{array}{l}\text { Average number of audit committee meetings held in one } \\
\text { financial year. }\end{array}$ \\
\hline AC attendance \% & ACA & $\begin{array}{l}\text { Average attendance percentage at the audit committee meetings } \\
\text { in one financial year. }\end{array}$ \\
\hline $\begin{array}{l}\text { No. of shares } \\
\text { held } \%\end{array}$ & ACS & Average shareholding percentage of audit committee members. \\
\hline $\begin{array}{l}\text { Other } \\
\text { Directorships }\end{array}$ & $\mathrm{ACD}$ & $\begin{array}{l}\text { Average number of outside directorships held by audit committee } \\
\text { members. }\end{array}$ \\
\hline Audit experience & $\mathrm{ACE}$ & $\begin{array}{l}\text { Percentage of audit committee members who were former } \\
\text { auditors. }\end{array}$ \\
\hline AC Size & ACSZ & Average size of the audit committee. \\
\hline $\begin{array}{l}\mathrm{AC} \\
\text { Remuneration }\end{array}$ & ACR & $\begin{array}{l}\text { Average compensation paid to audit committee members for } \\
\text { their services. }\end{array}$ \\
\hline AC Tenure & $\mathrm{ACT}$ & Average tenure of members of the audit committee members. \\
\hline \multicolumn{3}{|l|}{ Control Variables } \\
\hline External Auditor & BIG4 & Audited by big 4; PwC, Deloitte, EY, KPMG. \\
\hline
\end{tabular}


Table 2: Descriptive Statistics

\begin{tabular}{|c|c|c|c|c|c|c|c|c|c|c|c|c|}
\hline \multirow{2}{*}{ Variables } & \multicolumn{4}{|c|}{ Full Sample } & \multicolumn{4}{|c|}{ AEP Firms } & \multicolumn{4}{|c|}{ Non-AEP Firms } \\
\hline & Mean & STD & Min & Max & Mean & STD & Min & Max & Mean & STD & Min & Max \\
\hline ACFC & 0.197 & 0.401 & 0.000 & 1.000 & 0.182 & 0.395 & 0.000 & 1.000 & 0.205 & 0.408 & 0.000 & 1.000 \\
\hline $\mathrm{ACF}$ & 0.307 & 0.192 & 0.000 & 0.750 & 0.254 & 0.225 & 0.000 & 0.750 & 0.334 & 0.170 & 0.000 & 0.750 \\
\hline $\mathrm{ACQ}$ & 0.291 & 0.173 & 0.000 & 0.670 & 0.246 & 0.162 & 0.000 & 0.500 & 0.313 & 0.176 & 0.000 & 0.667 \\
\hline $\mathrm{ACM}$ & 4.210 & 1.390 & 1.000 & 9.000 & 4.500 & 1.626 & 3.000 & 9.000 & 4.068 & 1.246 & 1.000 & 7.000 \\
\hline $\mathrm{ACA}$ & 0.960 & 0.078 & 0.670 & 1.000 & 0.977 & 0.049 & 0.800 & 1.000 & 0.945 & 0.088 & 0.667 & 1.000 \\
\hline ACS & 0.398 & 2.230 & 0.000 & 12.940 & 1.184 & 3.805 & 0.000 & 12.942 & 0.004 & 0.007 & 0.000 & 0.036 \\
\hline $\mathrm{ACD}$ & 2.412 & 1.040 & 0.500 & 5.000 & 2.728 & 0.667 & 1.500 & 3.800 & 2.254 & 1.158 & 0.500 & 5.000 \\
\hline BIG4 & 0.849 & 0.361 & 0.000 & 1.000 & 0.636 & 0.492 & 0.000 & 1.000 & 0.955 & 0.211 & 0.000 & 1.000 \\
\hline $\mathrm{ACE}$ & 0.160 & 0.169 & 0.000 & 0.500 & 0.164 & 0.186 & 0.000 & 0.500 & 0.158 & 0.163 & 0.000 & 0.500 \\
\hline ACSZ & 4.091 & 1.049 & 2.000 & 7.000 & 3.955 & 0.950 & 2.000 & 5.000 & 4.159 & 1.098 & 2.000 & 7.000 \\
\hline ACR & 57859.03 & 24050.20 & 7245 & 133200 & 61194.39 & 21433.44 & 36666.67 & 132000 & 56191.35 & 25326.91 & 7245 & 133200 \\
\hline ACT & 4.431 & 2.042 & 0.500 & 11.333 & 5.708 & 2.256 & 3.000 & 11.333 & 3.793 & 1.601 & 0.500 & 7.750 \\
\hline
\end{tabular}

Notes: This table is a breakdown of the key statistics relevant to the data set. AC chair female $(A C F C)$, female audit committee (ACF), qualified accountant (ACQ), audit committee attendance $(A C A)$, number of shares held $(A C S)$, external auditor $(B I G 4)$, and audit experience $(A C E)$. Number of audit committee meetings $(A C M)$, other directorships $(A C D)$, audit committee size $(A C S)$, audit committee remuneration $(A C R)$, and board tenure $(A C T)$. 
Table 3: Correlation matrix

\begin{tabular}{|c|c|c|c|c|c|c|c|c|c|c|c|c|}
\hline Variables & $\mathrm{ACFC}$ & $\mathrm{ACF}$ & $\mathrm{ACQ}$ & $\mathrm{ACM}$ & $\mathrm{ACA}$ & ACS & $\mathrm{ACD}$ & BIG4 & $\mathrm{ACE}$ & ACSZ & ACR & ACT \\
\hline $\mathrm{ACFC}$ & 1 & & & & & & & & & & & \\
\hline $\mathrm{ACF}$ & 0.365 & 1 & & & & & & & & & & \\
\hline $\mathrm{ACQ}$ & 0.141 & 0.063 & 1 & & & & & & & & & \\
\hline $\mathrm{ACM}$ & 0.007 & 0.135 & -0.103 & 1 & & & & & & & & \\
\hline $\mathrm{ACA}$ & 0.007 & -0.029 & 0.031 & 0.069 & 1 & & & & & & & \\
\hline $\mathrm{ACS}$ & -0.089 & -0.286 & 0.043 & -0.156 & 0.102 & 1 & & & & & & \\
\hline $\mathrm{ACD}$ & 0.008 & 0.068 & -0.05 & 0.278 & 0.203 & 0.102 & 1 & & & & & \\
\hline BIG4 & -0.216 & 0.112 & 0.035 & 0.127 & -0.062 & -0.420 & -0.068 & 1 & & & & \\
\hline $\mathrm{ACE}$ & 0.069 & -0.066 & 0.620 & 0.019 & 0.063 & 0.181 & -0.124 & 0.084 & 1 & & & \\
\hline ACSZ & -0.08 & 0.245 & -0.041 & 0.156 & 0.061 & -0.186 & 0.068 & 0.321 & -0.020 & 1 & & \\
\hline ACR & -0.101 & 0.093 & -0.044 & 0.680 & 0.119 & -0.072 & 0.442 & 0.220 & 0.055 & 0.163 & 1 & \\
\hline $\mathrm{ACT}$ & -0.204 & -0.247 & -0.316 & -0.028 & 0.323 & 0.124 & 0.223 & -0.230 & -0.090 & -0.158 & 0.110 & 1 \\
\hline
\end{tabular}

Notes: This table illustrates the correlation which exists between all regressors utilised throughout this study. AC chair female $(A C F C)$, female audit committee $(A C F)$, qualified accountant $(A C Q)$, audit committee attendance $(A C A)$, number of shares held $(A C S)$, external auditor $(B I G 4)$, and audit experience $(A C E)$. Number of audit committee meetings $(A C M)$, other directorships $(A C D)$, audit committee size $(A C S)$, audit committee remuneration $(A C R)$, and board tenure $(A C T)$. 
Table 4: Regression Result

\begin{tabular}{lllllllll}
\hline Variables & \multicolumn{3}{c}{ Logistic Binary Model } & \multicolumn{3}{c}{ Two Stage Heckman Model } \\
\cline { 2 - 9 } & Coef. & Std. Err. & $z$ & P value & Coef. & Std. Err. & $z$ & P value \\
\hline ACFC & -0.36 & 1.15 & -0.32 & 0.75 & -1.88 & 1.53 & -1.23 & 0.22 \\
ACF & -0.59 & 2.51 & -0.23 & 0.82 & -14.02 & 5.75 & -2.44 & $0.02^{* *}$ \\
ACQ & -3.17 & 3.40 & -0.93 & 0.35 & 8.16 & 5.48 & 1.49 & 0.14 \\
ACM & 0.69 & 0.41 & 1.68 & $0.093 *$ & 0.34 & 0.70 & -1.69 & $0.09^{*}$ \\
ACA & -0.18 & 5.59 & -0.03 & 0.97 & -9.61 & 5.69 & 0.49 & 0.62 \\
ACS & 34.12 & 74.23 & 0.46 & 0.65 & -160.95 & 147.78 & -1.09 & 0.28 \\
ACD & 0.38 & 0.44 & 0.86 & 0.39 & -2.30 & 1.11 & -0.17 & 0.86 \\
BIG4 & -4.15 & 2.22 & -1.87 & $0.062 *$ & -18.73 & 2.61 & -7.17 & $0.00^{* * *}$ \\
ACE & 3.84 & 3.85 & 1.00 & 0.32 & -13.57 & 7.95 & -1.71 & $0.09 *$ \\
ACSZ & 0.22 & 0.41 & 0.53 & 0.59 & 0.91 & 0.60 & 1.51 & 0.13 \\
ACR & 0.00 & 0.00 & -0.80 & 0.42 & 0.00 & 0.00 & 0.88 & 0.38 \\
ACT & 0.66 & 0.29 & 2.30 & $0.021 * *$ & -0.07 & 0.40 & -2.07 & $0.04 * *$ \\
Constant & -3.16 & 5.26 & -0.60 & 0.55 & - & - & - & - \\
$\lambda$ & - & - & - & - & -1.87 & 0.80 & -2.34 & $0.02^{* *}$ \\
\hline
\end{tabular}

Note: $* * *$ and $* * *$ are used to show which variables are significant at $10 \%, 5 \%$ and $1 \%$ respectively. AC chair female $(A C F C)$, female audit committee $(A C F)$, qualified accountant $(A C Q)$, audit committee attendance $(A C A)$, number of shares held (ACS), external auditor (BIG4), and audit experience $(A C E)$. Number of audit committee meetings $(A C M)$, other directorships $(A C D)$, audit committee size $(A C S)$, audit committee remuneration $(A C R)$, and board tenure $(A C T)$. 


\section{Appendices}

\section{Appendix 1-AEP and Non-AEP firms}

\begin{tabular}{lll}
\hline AEP firms & Non-AEP comparable 1 & Non-AEP comparable 2 \\
\hline 1. Sports Direct & 1. JD Sports Fashion & 1. NEXT \\
International & 2. BAE Systems & 2. Senior \\
2. Rolls-Royce Holdings & 3. Vodafone Group & 3. Computacenter \\
3. BT Group & 4. Rentokil Initial & 4. Babcock \\
4. Mitie Group & 5. Morgan Sindall Group & 5. Galliford Try \\
5. Carillion & 6. Travis Perkins & 6. Grafton Group plc \\
6. SIG & 7. Hotel Chocolat Group & 7. Greggs \\
7. Patisserie Holdings & 8. Serco Group & 8. Morgan Sindall \\
8. Interserve & & Group \\
9. Thomas Cook Group & 9. InterContinental Hotels & 9. Air Partner \\
10. Laura Ashley Holdings & 10. Mothercare & 10. N Brown Group \\
11. Ted Baker & 11. Superdry & 11. N Brown Group \\
\hline \hline
\end{tabular}

Notes: all companies are PLCs. N Brown Group was used as a comparable twice over 2 separate periods that did not overlap. 
Appendix 2-Glossary of disclosures

\begin{tabular}{|c|c|c|}
\hline Author & Disclosure type & Description \\
\hline $\begin{array}{l}\text { Kelton and } \\
\text { Yang (2008) }\end{array}$ & Internet Financial Reporting & $\begin{array}{l}\text { Publicly available online disclosures } \\
\text { in both report and presentation format. }\end{array}$ \\
\hline Li et al (2012) & Intellectual Capital Disclosure & $\begin{array}{l}\text { Comprises of three major components: } \\
\text { human capital, structural capital and } \\
\text { relational capital }\end{array}$ \\
\hline $\begin{array}{l}\text { Mangena and } \\
\text { Pike (2005) }\end{array}$ & Interim Disclosure & $\begin{array}{l}\text { The level of disclosure in interim } \\
\text { reports. }\end{array}$ \\
\hline Persons (2009) & $\begin{array}{l}\text { Earlier Voluntary Ethics } \\
\text { Disclosure }\end{array}$ & $\begin{array}{l}\text { A combination of a written code of } \\
\text { business conduct and an ethics } \\
\text { committee separate to the board who } \\
\text { had an officer. All of which had to be } \\
\text { disclosed before } 15^{\text {th }} \text { July in the paper } \\
\text { to meet the criteria of early. }\end{array}$ \\
\hline
\end{tabular}

